\title{
Pengaruh practice based simulation model terhadap skill performance mahasiswa keperawatan
}

\author{
Retno Issroviatiningrum ${ }^{1}$, Suyanto Suyanto ${ }^{2}$ \\ ${ }^{1,2}$ Fakultas IImu Keperawatan, Universitas Islam Sultan Agung Semarang, Indonesia \\ *Coresponding Author: ners.ningrum@gmail.com
}

\begin{abstract}
Abstrak
Pendahuluan: Upaya untuk meningkatkan mutu pendidikan keperawatan khususnya untuk mendukung peserta didik menjadi perawat profesional memerlukan proses pembelajaran dengan menggunakan fasilitas keterampilan klinis melalui pendekatan problem based learning. Penelitian ini bertujuan untuk menganalisis pengaruh practice based simulation model terhadap skill perfomance mahasiswa keperawatan. Metode: Penelitian ini menggunakan Quasy - Experiment dengan pendekatan pretest-posttest with control group design. Pengambilan sampel dengan teknik simple random sampling dengan jumlah 21 responden baik kelompok intervensi maupun kontrol. Analisis data menggunakan uji Paired T-Test dan Independent Samples T-Test. Hasil: Selisih peningkatan skill performance pada kelompok intervensi sebanyak 11,47 poin dan kelompok kontrol sebanyak 2,29 poin. Practice based simulation model berpengaruh terhadap skill perfomance dengan nilai $p=$ $0,00<0,05$. Simpulan: Practice based simulation model memengaruhi skill perfomance mahasiswa keperawatan.
\end{abstract}

Kata kunci: Practice based simulation model; skill performance; mahasiswa

\section{The influence of practice based simulation model to skill performance student of nursing}

\begin{abstract}
Introduction: Efforts to improved the quality of nursing education, especially to support students to became professional nurses who require a learning process using clinical skills facilities through a problem-based learning approach. This study aims to analyze the effect of practice based on a simulation model on the performance of nursing student skills. Methods: This study used Quasy - Experiment with a pretest-posttest approach with control group design. Sampling using simple random sampling technique with a total of 21 respondents both the intervention and control groups. Data analysis used Paired T-Test and Independent Samples T-Test. Results: The difference in the increase in skill performance in the intervention group was 11.47 points and the control group was 2.29 points. The practice-based simulation model has an effect on skills performance with a value of $p=0.00$ $<0.05$. Conclusions: Practice-based simulation models affect the skill performance of nursing students.
\end{abstract}

Keywords: Practice based simulation model; skill performance; Student

How to Cite: Isrovianingrum, R., \& Suyanto, S. (2019). Pengaruh practice based simulation model terhadap skill performance mahasiswa keperawatan. NURSCOPE: Jurnal Penelitian dan Pemikiran IImiah Keperawatan, 5(2),

1-7

\section{PENDAHULUAN}

Pelayanan keperawatan yang berkualitas sangat perlu didukung oleh adanya sumber daya manusia, yaitu salah satunya adalah perawat yang dihasilkan oleh institusi pendidikan yang berkualitas sesuai standar yang telah ditetapkan sehingga mampu menghasilkan lulusan perawat yang mempunyai kompetensi sesuai level KKNI. Pendidikan keperawatan memegang peranan yang sangat penting dalam mewujudkan pelayanan kesehatan yang berkualitas. Hasil penelitian yang dilakukan oleh Lewis (2010) dalam Hakimzadeh (2013), faktor-faktor yang mempengaruhi kompetensi mahasiswa diantaranya adalah motivasi, lingkungan belajar, metode pembelajaran, desain kurikulum, dan keberhasilan akademik sebelumnya. Metode pembelajaran merupakan salah satu dari faktor yang mempengaruhi kompetensi dimana metode pembelajaran adalah cara yang digunakan oleh dosen untuk memilih dan merancang kegiatan belajar selama proses pembelajaran berlangsung. 
Upaya untuk meningkatkan mutu pendidikan keperawatan khususnya untuk mendukung peserta didik menjadi perawat profesional memerlukan proses pembelajaran dengan menggunakan fasilitas keterampilan klinis. Hal tersebut memberikan tempat yang ideal bagi pengembangan pembelajaran untuk profesi keperawatan. Penguasaan pada keterampilan klinik merupakan suatu elemen yang penting dari mutu profesional lulusan pendidikan tinggi keperawatan. Seringkali suatu institusi pendidikan profesi keperawatan dapat memberikan pengetahuan berupa teori atau konsep yang memadai pada peserta didiknya, tetapi kurang dalam memberikan keterampilan (prosedural knowledge) dan perkembangan sikap yang dibutuhkan dalam melakukan keterampilan tersebut (Suryadi, 2008).

Suryadi (2008) menyatakan alasan pokok mengapa laboratorium keterampilan klinis dasar perlu dikembangkan disetiap institusi pendidikan kesehatan/kedokteran adalah menanggapi perkembangan sistem pendidikan yang berdasar pada paradigma baru antara lain menggunakan pendekatan problem based learning dalam proses pembelajaran kurikulum berbasis kompetensi atau rumusan keluaran yang jelas dari institusi pendidikan, adopsi prinsip belajar orang dewasa dan belajar mandiri serta experiental learning, tuntutan pasien untuk dilayani yang mana pasien kurang dapat menerima perawatan jika dilakukan oleh pembelajar yang baru.

Menanggapi salah satu tantangan diatas dalam pendekatan problem based learning yaitu dapat menggunakan metode pembelajaran simulasi yaitu metode pembelajaran yang memberikan pembelajaran dengan menggunakan keadaan atau situasi yang nyata, dengan cara peserta didik terlibat aktif dalam proses berinteraksi dengan situasi lingkungannya (Nursallam, 2008). Practice based simulation model adalah model pembelajaran yang berpusat pada peserta didik yang dikembangkan dengan tujuan untuk mencapai integrasi simulasi yang efektif. Practice based simulation model didasarkan pada teori belajar konstruktif yang menegaskan bahwa pengetahuan tidak pasif ditransfer dari pendidik kepada peserta didik, tetapi dibangun oleh peserta didik melalui pengolahan pengalaman dan interaksi dengan lingkungan mereka (Parker \& Myrick, 2009).

Practice based simulation model didasarkan pada teori belajar konstruktif yang menegaskan bahwa pengetahuan tidak pasif ditransfer dari pendidik kepada peserta didik, tetapi dibangun oleh peserta didik melalui pengolahan pengalaman dan interaksi dengan lingkungan mereka (Parker \& Myrick, 2009). Pengalaman dan interaksi dengan lingkungan dapat menjadikan mahasiswa percaya diri dalam memutuskan dan melakukan suatu tindakan keperawatan yang akan dilakukan kepada pasien. Penelitian sebelumnya yang dilakukan oleh Sleeper \&Thompson (2008) menguatkan pendapat bahwa metode simulasi dapat meningkatkan self confidence peserta didik, sedangkan penelitian oleh Mahardika (2012) metode simulasi dapat meningkatkan clinical perfomance peserta didik, dan penelitian oleh Cordeau (2013) dengan metode simulasi sangat diperlukan guna meningkatkan kognitif, afektif dan psikomotrik peserta didik.

\section{METODE}

Penelitian ini merupakan jenis penelitian quasy eksperiment dengan pendekatan pretest-posttest with control group design. Populasi yang digunakan adalah mahasiswa semester VI Prodi S1 Keperawatan FIK Unissula Semarang. Pengambilan sampel dilakukan dengan teknik simple random sampling. Sampel yang digunakan dalam penelitian ini berjumlah 21 responden pada kelompok kontrol dan kelompok intervensi dan menggunakan instrument penilaian skill performance.

\section{HASIL DAN PEMBAHASAN}

Berdasarkan tabel 1 didapatkan mean IPK pada kelompok intervensi adalah 3.26 dengan IPK minimal adalah 3.02 dan IPK maximal adalah 3.69 dengan karakteristik belum pernah mendapatkan pengalaman simulasi sebelumnya dan semua memiliki kondisi fisik sehat. Sedangkan mean IPK pada 
kelompok kontrol 3.14 dengan IPK minimal 3.01 dan IPK maximal adalah 3.35 dengan karakteristik belum pernah mendapatkan pengalaman simulasi sebelumnya dan semua memiliki kondisi fisik sehat.

Tabel 1. Distribusi karakteristik responden dilihat dari IPK, pengalaman simulasi, kondisi fisik di FIK Unnisula Semarang ( $n=42$ )

\begin{tabular}{lcclc}
\hline \multicolumn{1}{c}{ Variabel } & $\mathbf{n}$ & Mean & SD & Min-max \\
\hline Kelompok intervensi & 21 & 3.26 & 0,17 & $3.02-3.69$ \\
Kelompok kontrol & 21 & 3.14 & 0,09 & $3.01-3.35$ \\
& \multicolumn{4}{c}{ Pengalaman Simulasi } \\
Kelompok intervensi & 21 & 0.00 & 0.000 & $0-0$ \\
& & & & $0-0$ \\
Kelompok control & 21 & 0.00 & 0.000 & \\
& & & & Kondisi Fisik \\
Kelompok intervensi & 21 & 1.00 & 0.000 & $1-1$ \\
Kelompok kontrol & 21 & 1.00 & 0.000 & $1-1$ \\
\hline
\end{tabular}

Tabel 2 menunjukkan bahwa rata-rata skill perfomance pada kelompok intervensi yaitu 65.05 sedangkan rata-rata skill perfomance pada kelompok kontrol yaitu 65.19. Sehingga dapat diketahui nilai mean lebih tinggi kelompok kontrol dibandingkan kelompok intervensi.

Tabel 2. Distribusi frekuensi skill perfomance mahasiswa keperawatan $(n=42)$

\begin{tabular}{lllcc}
\hline \multicolumn{1}{c}{ Variabel } & N & Mean & Min-max & SD \\
\hline Kelompok intervensi & 21 & 65.05 & $50-76$ & 6.637 \\
Kelompok kontrol & 21 & 65.19 & $51-76$ & 6.424 \\
\hline
\end{tabular}

Tabel 3 dapat diketahui bahwa skill perfomance pada kelompok intervensi saat pretest sebesar 65,05, pada posttest pertama menjadi 70,86 dan pada posttest kedua menjadi 76,52 . Perbedaan selisih nilai mean pada kelompok intervensi adalah 11,47 poin. Pada kelompok kontrol nilai saat pretest sebesar 65,19 , pada posttest pertama menjadi 66,57 dan postest kedua menjadi 67,48 . Perbedaan selisih nilai mean pada kelompok kontrol adalah 2.29 poin. Hal ini menunjukkan terjadinya peningkatan skill perfomance pada kelompok intervensi dan kelompok kontrol, tetapi perbedaan peningkatan lebih signifikan kelompok intervensi dibandingkan dengan kelompok kontrol. Berdasarkan analisis dengan menggunakan uji Paired T-Test menunjukkan adanya perbedaan peningkatan skill perfomance yang bermakna pada kelompok intervensi dan kelompok kontrol sebelum dan sesudah dilakukan intervensi.

Tabel 3. Perbedaan rerata nilai skill perfomance sebelum dan sesudah dilakukan intervensi $(n=42)$

\begin{tabular}{cccccc}
\hline Kelompok & $\mathbf{N}$ & Variabel & Mean & SD & $\boldsymbol{P}$ \\
\hline \multirow{2}{*}{ Intervensi } & \multirow{2}{*}{21} & Pre-test & 65,05 & 6,637 & 0.040 \\
& & Post-test 1 & 70,86 & 3,022 & 0.000 \\
& & Post -test 2 & 76,52 & 4,986 & 0.000 \\
\cline { 2 - 6 } Kontrol & \multirow{3}{*}{21} & Pre-test & 65,19 & 6,424 & 0.003 \\
& & Post-test 1 & 66,57 & 4,066 & 0.084 \\
& & Post-test 2 & 67,48 & 6,234 & 0.000 \\
\hline
\end{tabular}


Tabel 4 hasil uji statistik menggunakan uji Independen Sample T-Test dengan taraf signifikansi $5 \%$ diperoleh nilai t hitung skill performance sebesar 5.194 dengan nilai sig (p) $0.000<0.05$ maka artinya ada perbedaan skill perfomance pada kelompok kontrol dan kelompok intervensi. Responden pada kelompok intervensi dengan diberikan practice based simulation model memiliki skill perfomance yang lebih tinggi dibandingkan responden kelompok kontrol. Sehingga dapat disimpulkan ada pengaruh practice based simulation model terhadap skill perfomance mahasiswa.

Tabel 4. Perbedaan rerata skill perfomance setelah perlakuan practice based simulation model antara kelompok intervensi dan kelompok mahasiswa keperawatan $(n=42)$

\begin{tabular}{lccc}
\multicolumn{1}{c}{ Variabel } & T & Df & Sig \\
\hline $\begin{array}{l}\text { Kelompok intervensi } \\
\text { Kelompok control }\end{array}$ & 5.194 & 40 & 0.000 \\
\hline
\end{tabular}

Hasil penelitian menunjukkan bahwa responden kelompok intervensi mempunyai skill perfomance yang meningkat signifikan setelah mendapatkan intervensi dan menunjukkan bahwa practice based simulation model memberikan pengaruh yang signifikan terhadap skill pefomance. Kompetensi yang harus dimiliki seorang perawat yaitu mampu memberikan tindakan keperawatan yang bermutu tinggi. Guna mencapai keterampilan yang professional dalam memberikan tindakan keperawatan diperlukan proses belajar mengajar, saran dan prasarana yang berkualitas serta metode pembelajaran yang tepat dan efektif (Deden, 2013) Metode pembelajaran yang digunakan dalam praktikum yaitu demonstrasi dan simulasi (Simamora, 2011).

Simulasi adalah metode pembelajaran yang memberikan pembelajaran dengan menggunakan keadaan atau situasi yang nyata, dengan cara mahasiswa terlibat aktif dalam proses berinteraksi dengan situasi lingkungannya. Mahasiswa melakukan aplikasi terhadap pengetahuan dan keterampilan yang telah diperoleh sebelumnya guna untuk mengambil keputusan dalam melakukan tindakan keperawatan (Nursalam \& Efendi, 2008). Kelebihan simulasi yaitu dapat memperkaya pengetahuam, sikap dan keterampilan serta pengalaman yang tidak langsung diperlukan dalam menghadapi berbagai masalah social (Nursalam \& Efendi, 2008). Penelitian yang dilakukan oleh Mulati, dkk (2014) menunjukkan bahwa mahasiswa yang mendapat nilai sempurna lebih banyak pada kelompok yang diberikan metode pembelajaran simulasi dibanding kelompok kelompok yang diberikan dengan metode pembelajaran latihan/drill.

Practice based simulation model awalnya dikonsep oleh penulis pertama yang menggambarkan pengembangan, implementasi dan evaluasi Simulasi-Problem Based Learning (S-PBL) yang diterapkan pada kurikulum di Korea (Park et, al. 2009). Practice based simulation model itu sendiri adalah model pembelajaran berpusat pada peserta didik yang dikembangkan dengan tujuan untuk mencapai integrasi simulasi yang efektif. Practice Based Simulation Model didasarkan pada teori belajar konstruktif yang menegaskan bahwa pengetahuan tidak pasif ditransfer dari pendidik kepada peserta didik, tetapi dibangun oleh peserta didik melalui pengolahan pengalaman dan interaksi dengan lingkungan mereka (Parker \& Myrick 2009).

The Nursing Education Simulation Frame Work (NESF) menjelaskan bahwa outcomes dari simulasi itu sendiri adalah knowledge, skill perfomance, learner satisfaction, critical thinking dan self confidence. Dalam outcomes skill performance, penelitian yang dilakukan oleh Mahardika (2012) metode simulasi dapat meningkatkan clinical perfomance peserta didik, dan penelitian oleh Cordeau (2013) dengan 
metode simulasi sangat diperlukan guna meningkatkan kognitif, afektif dan psikomotorik peserta didik.

Penilaian berbasis performance umumnya terkait dengan keterampilan psikomotor. Misalnya menunjukkan kompetensi dalam mengukur tanda-tanda vital. Melakukan perawatan langsung salah satunya perawatan luka DM. Leanburg dalam Anema (2010), menyatakan bahwa penilaian performance meliputi kompetensi hasil yang relevan dengan perawatan dan profesi kesehatan lainnya yaitu penilaian dan intervensi, komunikasi, berpikir kritis, pengajaran, hubungan antar manusia, manajement, kepemimpinan dan integrasi pengetahuan. Mahasiswa dapat melaksanakan beberapa keterampilan pada manikin, dan melihat hasil yang menunjukkan apakah mereka melakukan prosedur dengan benar.

Practice based simulation model dengan menggunakan pasien simulasi yang sebelumnya sudah di briefing terhadap apa saja yang harus dilakukan selama simulasi berlangsung, melihatkan hasil yang menunjukkan mahasiswa harus membuat pilihan bersama dalam mengambil keputusan. Pengetahuan dasar berfungsi sebagai dasar untuk membuat keputusan. Misalnya tanda dan gejala, riwayat kesehatan dan nilai-nilai laboratorium, analisis krisis dan sintesis pengetahuan diperlukan. Seperti setiap keputusan yang ditetapkan, mahasiswa menerima umpan balik dan memiliki kesempatan untuk memilih tindakan keperawatan yang tepat dilakukan untuk mengatasi masalah dari pasien simulasi tersebut. Jika keputusan yang diambil tepat dan sesuai dengan hasil akhir yang diharapkan untuk mengatasi kasus pada pasien simulasi, mahasiswa dapat dikatakan mempunyai kompetensi dalam hal tersebut, sehingga mahasiswa dapat menunjukkan skill performance yang terbaik (Adkins, 2004 dalam Anema 2010).

Peningkatan pada nilai evaluasi pelaksanaan practice based simulation model pertama hingga kedua menunjukkan antusiasme mahasiswa yang cukup tinggi pada metode simulasi yang akan digunakan dalam proses belajar mereka. Metode simulasi ini dilakukan dengan berjalan baik dan sesuai prosedur yang ada. Dengan adanya penelitian ini mahasiswa akan disajikan kasus skenario terkait perawatan luka pada pasien DM pada pasien dengan gangguan neurologi, sehingga mahasiswa bisa belajar bagaimana merawat luka DM dengan luka yang dibuat semirip mungkin dengan kenyataan, dan melatih pasien dengan latihan rentang gerak dengan pasien simulasi. Dengan adanya penelitian ini mahasiswa dapat melakukan tindakan (skill performance) perawatan luka DM ketika dihadapkan dengan kasus yang dibuat mirip dengan kejadian sesungguhnya, sehingga bisa dijadikan bekal sebelum mahasiswa praktek di rumah sakit. Hal ini menunjukkan bahwa metode simulasi ini efektif untuk meningkatkan skill perfomance dalam proses belajar di laboratorium.

Pada kelompok kontrol dalam penelitian ini nilai mean pada kelompok intervensi dan kelompok kontrol sama-sama mengalami kenaikan, tetapi kelompok intervensi lebih signifikan kenaikannya dibandingkan dengan kelompok kontrol. Kelompok intervensi .mengalami kenaikan 11.47 poin dan kelompok kontrol 2.29 poin.

Kelompok kontrol dalam penelitian ini tidak diberikan practice based simulation model. Kenaikan pada kelompok kontrol pada saat dilakukan posttest dimungkinkan dari faktor-faktor yang mempengaruhi skill performance, Gibshon et al (1997) dalam Nursalam (2013) faktor-faktor yang mempengaruhi performance factor individu yaitu kemampuan dan ketreampilan (mental dan fisik), latar belakang (keluarga, tingkat sosial, pengalaman) dan demografi. Fisik yang dilihat dari segi kondisi fisik dapat mempengaruhi kemampuan seseorang dalam berpikir kritis. Ketika seseorang dalam kondisi sakit, sedangkan ia dihadapkan pada kondisi yang menuntut pemikiran matang untuk memecahkan suatu masalah, tentu kondisi seperti ini sangat mempengaruhi pikirannya sehingga seseorang tidak dapat berkonsentrasi dan berpikir cepat. Dalam hal ini, kondisi fisik antara kelompok kontrol dan kelompok intervensi tidak berbeda yaitu dalam kondisi fisik sehat semuanya. 
Faktor lainnya adalah IPK. Mean IPK pada kelompok kontrol dengan kelompok intervensi tidak jauh berbeda yaitu mean IPK kelompok kontrol 3.22 dan IPK kelompok intervensi 3.23, hanya beda 0.01 poin. Perkembangan intelektual berkenaan dengan kecerdasan seseorang untuk merespon dan menyelesaikan suatu persoalan, menghubungkan atau menyatukan satu hal dengan yang lain, dan dapat merespon dengan baik terhadap stimulus. Sedangkan faktor yang lain adalah pengalaman simulasi. Pada kelompok kontrol, mahasiswa tidak diberikan simulasi sedangkan pada kelompok intervensi mendapatkan dua kali simulasi sehingga terdapat perbedaan selisih yang signifikan.

Di dalam pelaksanaan practice based simulation model mahasiswa kelompok intervensi tidak dikarantina sehingga memungkinkan mahasiswa antar kelompok intervensi dan kelompok kontrol saling berkomunikasi terkait practice based simulation model tersebut. Dapat disimpulkan dari hasil statistik dan tinjauan teori yaitu kelompok kontrol mengalami kenaikan pada mean pada nilai pretest ke posttest karena dipengaruhi beberapa faktor, diantaranya adalah faktor kondisi fisik, IPK dan pengalaman simulasi, serta adanya komunikasi antara kelompok intervensi dan kelompok kontrol terkait intervensi yang diberikan.

\section{SIMPULAN DAN SARAN}

Penelitian ini menghasilkan kesimpulan bahwa terdapat pengaruh practice based simulation model terhadap skill perfomance mahasiswa keperawatan. FIK Unnisula dapat mempertimbangkan dalam menggunakan metode PBSM sebagai inovasi metode pembelajaran di laboratorium, dan mempersiapkan video baku terkait tindakan keperawatan yang diajarkan.

\section{DAFTAR PUSTAKA}

Alimul, A. (2009). Metode Penelitian Keperawatan dan Tekhnik Analisis Data. Jakarta: Salemba Medika.

Al-Uqshari, Y. (2005). Percaya Diri Pasti. Jakarta: Gema Insani.

Angelis, B.D. (2007). Percaya Diri: Sumber Sukses dan Kemandirian. Jakarta: PT. Gramedia Pustaka Utama.

Aunurrahman. (2010). Belajar dan Pembelajaran. Cetakan ke-4. Bandung: Alfabeta.

Cordeau, M. A. (2013). Teaching holistic nursing using clinical simulation. A pedagogical essay. Journal of Nursing Education and Practice. 3(4): 40-50.

Hakim, T. (2002). Mengatasi Rasa Tidak Percaya Diri. Jakarta: Puspa Swara.

Hakimzadeh, et,al. (2013). Factors Afecting the Teaching-learning in Nursing Education. E-ISBN978967-11768---0-1.

Hicks, F., \& Coke, L. (2009) The effect of High-Fidelity simulation on nursing students' knowlwdege and performance: Apolot study. National Council of State of Nursing, Inc. (NCSBN).

Jeffries, P. (2005). A framework for designing, implementing, and evaluating: simulations used as teaching strategies in nursing. Nursing Education Perspectives, 26(2), 96-103.

Notoatmodjo, S. (2010). Metodologi Penelitian Kesehatan. Jakarta : Rineka Cipta.

Nursalam \& Efendi, F. (2008). Pendidikan Dalam Keperawatan. Jakarta : Salemba Medika. 
Omer, T. (2016). "Nursing Students Perseptions Of Satisfaction And Self Confidence With Clinical Simulation Experience".Journal of Education and Practice Vol.7, No.5.

Park, M.Y. et, al. (2009). Simulation-PBL (Problem Based Learning): An evaluation of the implementation of learning modules in the Korean nursing context. In International Meeting on Simulation in Healthcare. Lake Buena Vista, FL: Society for Simulation in Healthcare.

Sufirmansyah. (2015). Pengaruh efikasi diri terhadap Prestasi belajar mahasiswa Pascasarjana Prodi PAI STAIN Kediri Dengan motivasi sebagai variabel Intervening. Didaktika Religia Volume 3 No. 2. 